\section{Privatizing U.S. Social Security: Some Possible Effects on Inter- generational Equity and the Economy}

\section{Laurence J . Kotlikoff}

$\mathrm{n}$ the early 1980s, when Chile first privatized its social security system, few observers could have predicted that its action would precipitate the worldwide interest in privatization that prevails today. In large part, the current interest grows out of a belief that privatizing social security can enhance national economic growth and lead to a higher standard of living for workers and retirees. Indeed, many analysts have attributed Chile's current economic success to social security privatization. Whether that is actually the case will no doubt be a subject for study by economic historians for years to come. In the meantime, a question that many researchers and others are asking is "Will privatization yield the expected benefits in the United States?"

Among the researchers who have studied this question are Seidman (1986) and Feldstein (1995), who use partial equilibrium frameworks, and Arrau (1990), Arrau and Schmidt-Hebel (1993), Raffelhuschen (1993), and Huang, Imrohoroglu, and Sargent (1997), who use general equilibrium frameworks.

This article uses simulations in a stylized model-the Auerbach-Kotlikoff Dynamic Life Cycle model - to explore some possible economic outcomes of privatizing Social Security in the United States: first, the poten- tial impact on the macro economy; second, how different generations may be affected (in particular, whether privatization will enhance or undermine intragenerational equity); and, third, some efficiency gains that might arise from privatization.

The parameters in this model (hereinafter referred to as the A-K model) closely parallel those of U.S. economic conditions and fiscal policies. In addition, the model has more detailed equilibrium frameworks than those in the other models cited above. Previously used in a number of simulation studies (see Kotlikoff, 1996 and 1998, and Kotlikoff et al., 1997 and 1998), the A-K model has recently been enhanced to include intragenerational heterogeneity, kinked budget constraints, and a more realistic formulation of incometaxation.

All the variations of the A-K model comprise three basic elements: (1) workers are required to contribute to private retirement accounts, (2) social security benefits are awarded to those who are workers and retirees during the transition in accordance with the benefits they have accrued before the transition, and (3) these transitional benefits are paid for by means of a wage tax, an income tax, a consumption tax, or a combination of income taxes and deficit financing. Simulations in the A-K model indicate that the long-run effects on the macro economy differ substantially from the short-run effects, depending on how the transition is financed. Because consumption-tax financing produces much more rapid economic gains than either wage- or income-tax financing (see Kotlikoff et al., 1997 and 1998), I discuss only the consumption-tax simulation in this article.

\section{MACROECONOMIC CONCERNS}

Privatization is often espoused as a means to stimulate long-run economic growth. If this is to happen, however, the supplies of labor and capital must increase. One way to stimulate increases in labor and capital is to reduce the effective tax rate on wages (by eliminating the Social 
Security tax). When workers collect a larger portion of their earnings, they have more incentive to work, and when they work more, their increased earnings allow them to save more, so that ultimately labor supply, national income, saving, and capital formation all increase.

The above analysis ignores the transition costs of privatization, however. The obligations to retirees and older workers must be financed. Replacing a Social Security tax with a transition tax on wages will increase labor supply only to the extent that the overall tax burden declines. Kotlikoff et al. (1997 and 1998) have shown that using a consumption tax to finance the transition provides the least distortion and hence raises labor supply the most.

\section{INTRAGENERATIONAL EQUITY}

Will privatization enhance or undermine generational equity? The U.S. Social Security System, like systems in many other countries, aims at intragenerational equity by providing benefits on a progressive scale. That is, it relates benefits to past earnings. But because the poor tend to die at earlier ages than the rich, and therefore may not be around to collect their benefits as long as those who are better off financially, the system is actually less progressive than is commonly believed. While privatizing the U.S. system would eliminate its progressive benefits schedule at the margin, it might entail little or no annuitization of individual account balances; thus, under the system in the A-K model, heirs of persons who die young could inherit much or all of the decedents' account balances. The actual outcome would depend on the new system's withdrawal and bequest rules, but reversing the annuitization of the elderly's resources could have important implications for intragenerational equity over time.

\section{EFFECTS ON EFFICIENCY GAINS}

The recent announcement by Social Security actuaries that, over the previous 20 years, they had made a mistake amounting to almost $\$ 1$ billion in calculating retirees' benefits emphasizes the complexities of our present Social Security System, which can be daunting to the experts, let alone the average worker. It is little wonder that most workers have a very difficult time determining, at the margin, just how much return they will receive on their marginal Social Security contributions. As a result, most may tend to treat the entire 15.3 percent Social Security payroll tax as an effective marginal tax on their labor supply. And since most workers who contribute to Social Security at the margin face additional federal as well as state labor tax rates totaling roughly 25 percent, the system in effect raises their total marginal tax rates by approximately 60 percent. The efficiency cost of distortionary taxation rises with the square of the effective tax rate; therefore, adding a 15 percent payroll tax to a 25 percent effective labor income tax increases the distortion of worker labor supply by roughly 150 percent.

In contrast, privatizing Social Security would eliminate the labor-supply distortion associated with the payroll tax. Few solutions are as simple as they seem, however; the method used to finance accrued Social Security benefits during the transition will introduce a new and different set of distortions. Just how significant the distortion turns out to be will depend on the method chosen. Kotlikoff et al. (1997 and 1998) show that consumption-tax financing would yield larger efficiency gains than other proposed methods because this tax is in effect a one-time wealth tax-that is, when individuals spend a portion of their wealth, they must pay a tax.

\section{THE A-K MODEL}

Having reviewed some of the concerns involved in moving to privatization, we can now examine some details of the $A-K$ model before moving on to the simulation outcomes. There are three economic sectors in the model: government, firms, and households, and the time paths of all economic variables in the model's economy are calculated over a 150year period. The two-part government sector consists of a treasury that collects funds from the private sector to pay for government operations and an unfunded, 
"pay-as-you-go" social security system that levies payroll taxes and distributes benefit payments. Since there is no money in the model, there is no monetary policy. Perfectly competitive firms use a Cobb-Douglas production function, hiring labor and capital to maximize profits.

\section{Generations and Income Classes}

There are 55 overlapping generations with a work-life span of 55 years each (from age 20 to age 75). The population growth rate in the model is a constant 1 percentthat is, each generation is 1 percent larger than the previous one- and within each generation are 12 different earnings classes, according to a pattern established by Fullerton and Rogers (1993). The income groupings are by deciles, with the bottom and top deciles subdivided into two classes each: Class 1 represents the lowest 2 percent and Class 2 the remaining 8 percent of the bottom decile, while Class 12 represents the top 2 percent and Class 11 the 8 percent immediately below it.

The wages for all income classes grow at the same rates, and they are set to reproduce the relative differences between classes estimated by Fullerton and Rogers (1993). In this simulation of the A-K model, the lowest level of earnings, in Class 1 , is $\$ 3.50$ per hour for a worker at age 20 . The starting wage level for the median income class is approximately $\$ 13$ per hour, and for the top 2 percent it is $\$ 36$ an hour. As the model's agents grow older, they receive a realistic series of wage increases amounting to 45 percent over the 55-year cycle and peaking at year 45 (age 65). Annual income from labor ranges from $\$ 10,000$ to $\$ 110,000$. The individual's age-wage profile is separate from the general level of wages, the time path of which is determined in solving the model.

\section{Factors Affecting Spending and Saving}

Fiscal policies affect households by altering the after-tax value of their wages, rates of return, and (in the case of a consumption tax) prices of goods and services. Since all the classes in the model experience the same longitudinal earnings growth and all agents are assumed to have the same preferences, differences in their behavior arise solely from differences in their economic opportunities, which vary with their class. This heterogeneity enables us to study the effects of privatization on the intragenerational distribution of economic resources and welfare.

Individual agents or households in the model base their decisions concerning how much to work and how much to save on their after-tax wages and the after-tax rates of return on their labor and their savings- both in the present and in the future. They also decide when to retire. The timeseparable CES consumption and leisure preferences that govern these decisions are based on evidence from actual labor supply and saving behavior.

\section{Social Security Benefits}

Replacement rates, the ratio of retirement benefits to pre-retirement earnings, are calculated by the U.S. Social Security System's benefit calculation formula. Applying this formula, we obtained lifetime income replacement rates ranging from 50 percent for the poorest income class to 20 percent for the richest. To allow the model to take survivor benefits into account and reproduce the current system's Old-Age and Survivor's Insurance (OASI) payroll tax rate of 10 percent, the replacement rates were scaled up by 60 percent.

This version of the A-K model also incorporates the 1995 ceiling of $\$ 61,200$ on taxable payroll earnings, making the maximum payroll tax base smaller than the maximum labor income. As a result, decisions by agents in the classes with the highest lifetime earnings regarding how much and/or how long to work are not distorted by consideration of payroll taxes, because the marginal payroll tax for such persons is zero.

Medicare and Disability Insurance

A flat (non earnings-related) benefit for agents over age 65 in our model 


\section{Table 1}

Macroeconomic Effects of Privatization (percentage change relative to the baseline)

Uncompensated Welfare

\begin{tabular}{lrrrr} 
& \multicolumn{4}{c}{ Year of Privatization } \\
\cline { 2 - 5 } & \multicolumn{1}{c}{5} & 10 & 25 & \multicolumn{1}{c}{150} \\
\hline Capital stock & & & & \\
Labor supply & & 7.7 & 17.0 & 36.7 \\
Output & 2.3 & 2.6 & 2.6 & 3.7 \\
Real wages & 2.7 & 3.3 & 6.1 & 11.2 \\
Real interest rate & 0.3 & 1.4 & 3.4 & 7.1 \\
& -1.0 & -4.0 & -9.4 & -18.7
\end{tabular}

Compensated Welfare

\begin{tabular}{lrrrr} 
& \multicolumn{4}{c}{ Year of Privatization } \\
\cline { 2 - 5 } & \multicolumn{1}{c}{5} & 10 & 25 & 150 \\
\hline Capital stock & 1.2 & 2.5 & 5.5 & 8.5 \\
Labor supply & 1.8 & 1.7 & 2.8 & 5.3 \\
Output & 1.7 & 1.9 & 3.5 & 6.1 \\
Real wages & -0.1 & 0.2 & 0.4 & 0.4 \\
Real interest rate & 0.4 & -0.6 & -1.9 & -2.2
\end{tabular}

${ }^{1}$ Since, in the simulations, only the poorest 2 percent of agents (Class 1) actually borrow against their savings and the amounts they borrow are rela. tively small, adding a liquidity constraint would not be expected to alter the conclusions significantly. percent, and the average rate is 39.7. For median earners, the top marginal rate is approximately 26.3 percent, and the

\section{MODELING PRIVATIZATION \\ Privatizing Social Security generally} involves three measures: (1) requiring workers to contribute to private retirement accounts, (2) providing retirees and current workers Social Security benefits equal to only those benefits they have accrued at the time privatization is implemented, and (3) financing these accrued benefits. In the A-K model, privatization requires simply eliminating the Social Security payroll tax. Because agents are not liquidity constrained, they cannot be forced to save. If agents are required to place a higher-than-desired percentage of their income in probate retirement accounts, they will offset this forced saving by borrowing against these accounts. ${ }^{1}$ In the model, the phasing out of Social Security benefits begins 10 years after privatization occurs. That way, current retirees (those 65 to 74 years old when the reform is initiated) receive the same benefits they would have received in the absence of privatization. Starting in the 11th year of the reform, Social Security benefits are phased out by 2.2 percent (of the baseline benefits) per year for 45 years. Thus, the transition to a fully privatized system takes an entire model lifetime ( 55 years).

During the transition period, the accrued Social Security benefits are financed by a proportional consumption tax. This tax starts at 9 percent and declines to zero by the end of the transition period. Privatizing Social Security also alters the income-tax base. Since, in the simulations, a constant level of government purchases per effective worker is maintained, the progressive income-tax rates are adjusted to account for privatization-induced changes over time in the income-tax base. The formula for the average progressive income tax rate, $\tau$, is $\tau=\alpha+\beta(\mathrm{B} / 2)$, where $\mathrm{B}$ is the income tax base. In lowering $\alpha$, holding $\beta$ fixed, we lower the income tax rates facing all agents, but by a greater percentage for agents with lower income 


\section{FINDINGS}

This section examines the macroeconomic and welfare effects of privatizing Social Security, financing the transition by means of consumption taxation. Simulations of the model indicate that such a reform would have both short-term and long-term macroeconomic benefits-the capital stock (K), labor supply (L), output (Y), and real wages ( $\mathrm{W}$ ) would all be above their baseline levels (the levels in the absence of privatization), while the real interest rate ( $r$ ) would fall. These results areillustrated in the top half of Table 1 and Figure 1.

The long-run macroeconomic gains are striking: The capital stock increases by 36.7 percent relative to the baseline, aggregate labor supply increases by 3.7 percent, output increases by 11.2 percent, and real wages increase by 7.1 percent. In addition, the real interest rate falls by 18.7 percent. While these long-run gains are impressive, they do not occur instantaneously. The transition's halflife is roughly 25 years. The lengthiness of this transition is partly a result of the gradual reduction in Social Security benefits and the consequent need to finance these benefits. The use of a consumption tax to finance these benefits provides for the fastest transition in terms of macroeconomic benefits, since such a tax produces redistribution from retirees to workers. Because retirees have higher propensities to consume than do workers, this redistribution results in a decline in aggregate consumption and a rise in saving. In addition, the consumption tax temporarily raises the price of consumption, providing all agents with an incentive to substitute saving for consumption. Nevertheless, these sharp rises in saving rates change the magnitude of the capital stock very gradually. ${ }^{2}$

The success of any privatization effort depends not only on the aggregate benefits to the economy but the effect on the wellbeing of the individuals in the economy. As the top portions of Table 2 and Figure 2 illustrate, in the model privatization provides welfare gains across all income classes in the long run. Moreover, the gains are inversely proportional to the income class. Thus, the lifetime utility of the poorest 2 percent (Class 1) of agents rises by 9.0 percent in the long run, while that of the wealthiest 2 percent

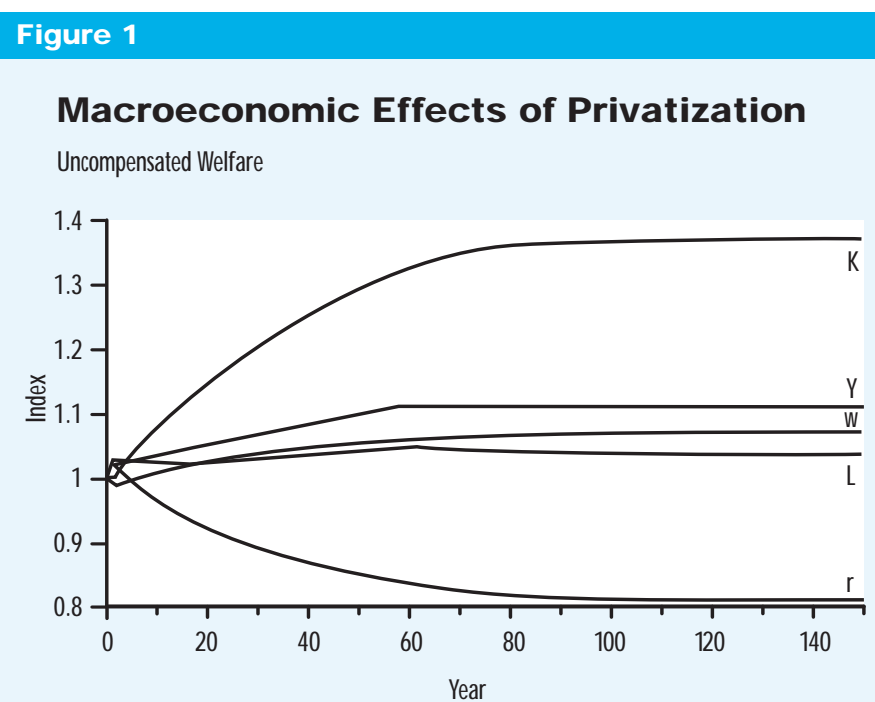

Compensated Welfare

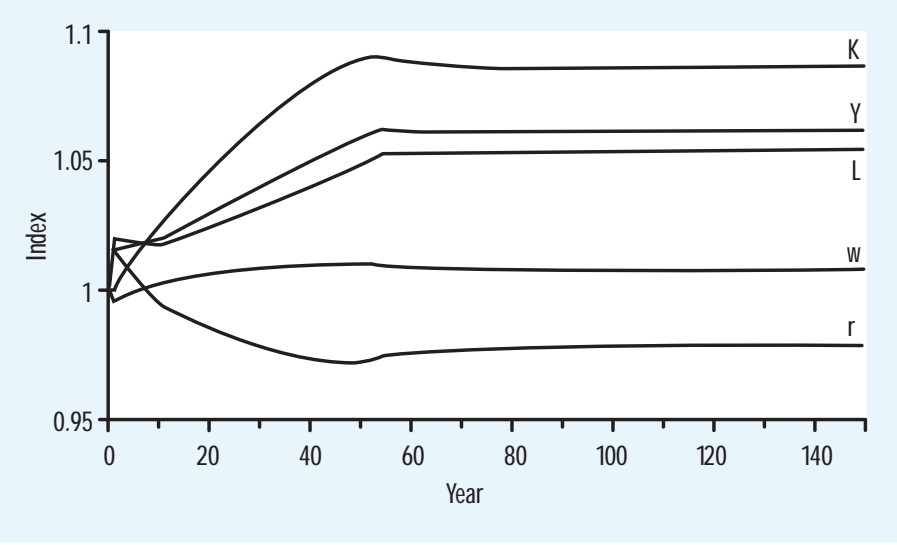

(Class 12) of agents rises by only 5.4 percent. This is a noteworthy outcome in light of the fact that privatizing Social Security entails abandoning what is considered to be a highly progressive Social Security benefits schedule.

There are two reasons that privatization is, in the long run, progressive. First, the intercept adjustment $(\alpha)$ of income tax rates in response to the tax-base increase favors lower-income agents over higher-income agents. Second, the ceiling on taxable earnings under the current Social Security System means that the implicit tax associated with being forced to contribute to a pay-as-you-go social security system is a larger factor for low earners, relative to their lifetime resources.

The increases in lifetime utility in the long run come at the cost of non-trivial welfare losses for the older agents alive at
2 See Auerbach and Kotlikoff (1987) for an analysis of policy-induced economic transitions. 


\section{Table 2}

\section{Remaining Lifetime Utility for Selected Income Classes and Cohorts}

(percentage change relative to the baseline)

Uncompensated Welfare

\begin{tabular}{|c|c|c|c|c|c|c|c|}
\hline \multirow[b]{2}{*}{ Income Class } & \multicolumn{7}{|c|}{ Year of Birth } \\
\hline & -54 & -25 & -10 & 0 & 10 & 25 & 150 \\
\hline Class 1 & -4.5 & -1.6 & 1.0 & 2.6 & 3.7 & 6.0 & 9.0 \\
\hline Class 3 & -4.0 & -1.5 & 1.2 & 2.6 & 3.6 & 5.7 & 8.4 \\
\hline Class 6 & -3.8 & -1.3 & 1.3 & 2.6 & 3.7 & 5.6 & 8.1 \\
\hline Class 9 & -3.7 & -1.1 & 1.4 & 2.7 & 3.7 & 5.5 & 7.9 \\
\hline Class 12 & -3.5 & -1.3 & -0.1 & 0.8 & 1.7 & 3.4 & 5.4 \\
\hline
\end{tabular}

Compensated Welfare

\begin{tabular}{|c|c|c|c|c|c|c|c|}
\hline \multirow[b]{2}{*}{ Income Class } & \multicolumn{7}{|c|}{ Year of Birth } \\
\hline & -54 & -25 & -10 & 0 & 10 & 25 & 150 \\
\hline $\begin{array}{l}\text { All income } \\
\text { dasses }\end{array}$ & 0.0 & 0.0 & 0.0 & 1.7 & 1.7 & 1.7 & 1.7 \\
\hline
\end{tabular}

${ }^{3}$ The use of lump-sum nature of the taxes and transfers ensures that they do not distort the labor supply decisions of agents in the model. If lump-sum taxes and transfers are not available the efficiency gains and macroeconomic benefits discussed below would be reduced.

${ }^{4}$ For an analysis of these issues see Kotlikoff et al. (1998). the time of the transition. The burden is greatest for those who are elderly at the time of the transition period, since they tend to have higher consumption levels and their opportunities for wage increases are diminishing or nonexistent. For example, those in the 5th percentile (Class 6) who were born 54 years prior to the start of the transition (those age 74 when privatization occurs) experience a 3.8 percent drop in their remaining lifetime utility. Furthermore, the decline in welfare experienced by the oldest cohorts falls most heavily on those in the lowest income classes.

All generations entering the workforce after the start of the transition experience net welfare gains resulting from privatization. In fact, most income classes of agents who are in their early work years when the transition occurs experience small positive welfare benefits. The only exception is the wealthiest 2 percent of agents (Class 12), whose remaining lifetime utility falls by 0.1 percent.

\section{Efficiency Gains}

The result that privatization is welfareenhancing in the long run but welfare- decreasing in the short run raises an important question: Can a privatized U.S. Social Security System be Pareto improving? That is, can the unborn winners compensate the existing losers, leaving no agent in any generation worse off and at least some of them better off? To accomplish this result, the model contains a Lump Sum Redistribution Authority (LSRA) - a hypothetical government agency that can redistribute resources among the different members of current and future generations by means of lump-sum taxes and transfers. ${ }^{3}$

The LSRA ensures that (1) all agents who are alive at the start of the transition experience the identical level of utility during the transition that they would have experienced in the absence of privatization (deviation from the baseline is zero); and, (2) all agents born at the time of the reform and thereafter experience an identical percentage increase in their utility. In the latter case, the utility increase is measured by the percentage change in lifetime consumption and leisure patterns that would have been needed in the old steady state to generate the level of utility enjoyed as a result of the privatization.

The simulation results indicate that the efficiency gains can be substantial. As shown in the bottom portions of Table 2 and Figure 2 , these gains are 1.7 percent. However, there is no guarantee that reducing the labor supply distortions through privatizing Social Security will make the economy more efficient. Such a result depends on how privatization is financed and the degree to which Social Security benefits are perceived to be linked to Social Security payroll taxes. ${ }^{4}$

A comparison between the results from the uncompensated and the compensated welfare plans indicates that in the long run generations have a higher lifetime utility under the former. N evertheless, it is important to note that most of the long-run welfare gains to future generations in the uncompensated case come at the expense of the generations of persons who are alive at the time of the transition.

As the tables and figures make clear, the need to compensate initial generations reduces the long-run performance of the economy relative to the uncompensated case. For 
example, the long-run level of economic output is 6.1 percent above the baseline when welfare is compensated; this figure rises to 11.2 percent when welfare is uncompensated. The capital stock and real wages are similarly lower in the compensated case, and the real interest rate is higher.

\section{CONCLUSION}

The simulation results indicate that privatization of the Social Security System and financing the transition with a consumption tax can have positive effects on both the performance of the economy and the welfare of individuals in the economy. The long-run capital stock (per person) rises by more than one-third, and the level of output increases by more than 10 percent. The welfare of future generations rises, with the added bonus that those at the low end of the income distribution receive the highest welfare gains. However, older workers at the start of the transition experience significant welfare losses. Thus, the extent to which privatization results in efficiency gains depends on the ability of future generations to compensate current workers for the loss of consumption as a result of financing the transition.

\section{REFERENCES}

Arrau, Patricio. Social Secunity Reform: The Capital Accumulation and Intergenerational Distribution Effect, The World Bank, 1990.

Arrau, Patricio, and Klaus Schmidt-Hebbel. "Macroeconomic and Intergenerational Welfare Effects of a Transition from Pay-As-You-Go to Fully Funded Pensions," Policy Research Department, Macroeconomics and Growth Division, The World Bank, 1993.

Auerbach, Alan I., and Laurence J. Kotlikoff. Dynamic Fiscal Policy, Cambridge University Press, 1987

Feldstein, Martin, "Would Privatizing Social Security Raise Economic Welfare?" mimeo, Harvard University, August 1995

Fullerton, Don, and Diane Lim Rogers. Who Bears the Lifetime Tax Burden? The Brookings Institution, 1993.

Huang, He, Selahattin Imrohoroglu, and Thomas J. Sargent. "Two Computations to Fund Social Security," Macroeconomic Dynamics (1997:1), pp. 7-44.

Kotlikoff, Laurence ). "Simulating the Privatization of Social Security in General Equilibrium," forthcoming in Privatizing Social Security, Martin S. Feldstein, ed., University of Chicago Press, 1998.

\section{Figure 2}

Remaining Lifetime Utility

(by income class)

Uncompensated Welfare

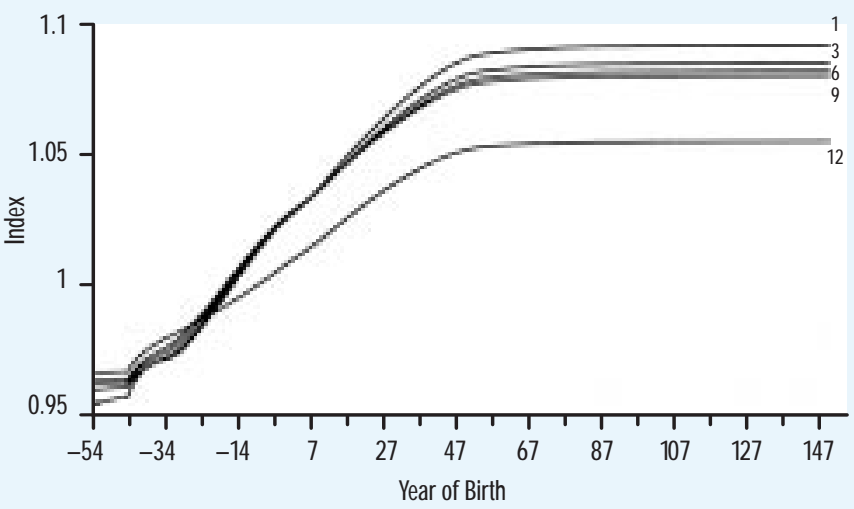

Compensated Welfare

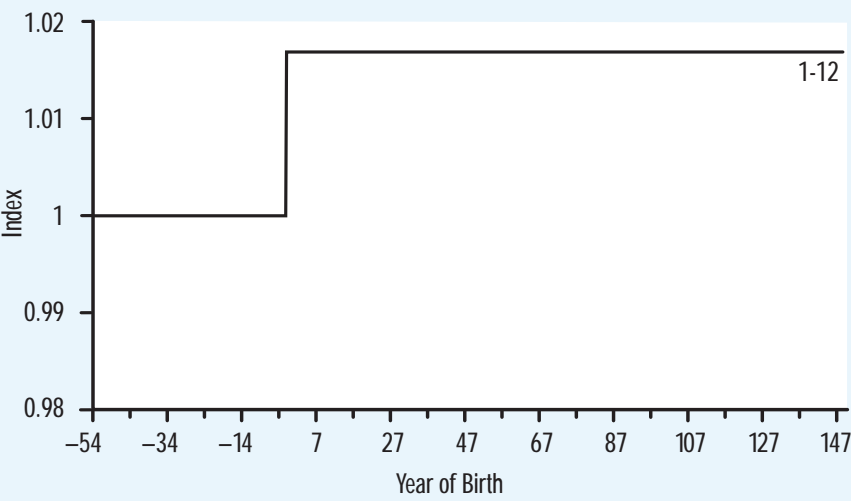

"Privatizing of Social Security: How It Works and Why It Matters," in Tax Policy and the Economy, Vol. 10, James M. Poterba, ed., MIT Press, 1996, pp.1-32.

, Kent Smetters, and Jan Walliser. "Privatizing U.S. Social Security - A Simulation Study," forthcoming in Pension Systems: From Crisis to Reform, Klaus Schmidt Hebbel, ed., The World Bank, 1998.

and "The Economic Impact of Privatizing Social Security," paper presented at the 1997 Kiel Week Conference held at the Kiel Institute of World Economics, June 26-27, 1997

Raffelhüschen, Bernd, "Funding Social Secunity through Pareto-Optimal Conversion Policies," Public Pension Economics, Bernhard Felderer, ed., Journal of Economics/ Zeitschrift fur National'konomie (Suppl. 7 1993), pp. 105-31.

Seidman, Laurence S., "A Phase-Down of Social Security: The Transition in a Life Cycle Growth Model," National Tax Journal (March, 1986), pp. 97-107. 